\title{
Biochemical Methane Potential of Palm Oil Mill Effluent (POME) Co-Digested with Rubber Latex Effluent (LTE): Effect of POME/LTE Ratio and Temperature
}

\author{
Nattawut YINGTHAVORN ${ }^{1}$, Laddawan NOYNOO ${ }^{1}$, \\ Tammathat BOONKAMNERD ${ }^{1}$, Nirattisai RAKMAK ${ }^{1,2}$ and \\ Chairat SIRIPATANA ${ }^{1,2, *}$
}

\author{
${ }^{1}$ School of Engineering and Technology, Walailak University, Nakhon Si Thammarat 80160, Thailand \\ ${ }^{2}$ Biomass and Oil-Palm Center of Excellence, Walailak University, \\ Nakhon Si Thammarat 80160, Thailand
}

('Corresponding author's e-mail: schairat61@gmail.com)

Received: 4 March 2019, Revised: 22 October 2019, Accepted: 4 November 2019

\begin{abstract}
Single anaerobic digestion of rubber latex effluent (LTE) is known to be difficult and low yield which produces biogas containing high sulfur dioxide and ammonia. This article investigates the potential of co-digestion of palm oil mill effluent (POME) and LTE both in terms of synergistic, inhibitory effects and process stability particularly in inferring what would happen in an industrial-scale biogas plant if this type of co-digestion is to be used. The article focuses on the biochemical methane potential (BMP) of POME-LTE at different mixing ratio within the temperature range of $30-45^{\circ} \mathrm{C}$, the range which is used in most commercial biogas power plants in Thailand. It was found that proper co-digestion between POME and LTE provided a good opportunity to optimize the bio-methane yield because of their synergistic effect. All mixing ratios provided stable biogas production up to at least 45 days. Co-digestion of POME and LTE had a synergistic effect that when mixing $80-90 \%$ of POME with $10-20 \%$ of LTE, it enhanced the BMP by $25-35 \%$. It is also recommended that, in mesophilic range, $45{ }^{\circ} \mathrm{C}$ would be the best for both methane yield and high methane content in the biogas. We also have illustrated that 2substrate models (in this case the Gompertz 2 substrate (GTS) model) is very suitable for representing and describing co-digestion data because of their inherently multiple substrate tendency. In most cases, Gompertz-type equations for single substrate did not represent the accumulated biogas/methane data adequately.
\end{abstract}

Keywords: BMP, POME: LTE ratio, Temperature, Anaerobic co-digestion, GTS modeling

\section{Introduction}

Natural rubber is a global commodity of which Thailand is the largest producer followed by Indonesia and Malaysia, respectively. In 2014, Thailand produced 4.09 million tons of natural rubber which was accounted to $32 \%$ of total world production and valued at 5,662 million USD. Southern Thailand contributes to $69 \%$ of total rubber plantation in the country and it is the main economic crop of the region [10]. Thus, most rubber manufacturing facilities are in Southern Thailand where rubber latex effluent is generated in large amount and require costly treatment before being released into the natural waterways. The concentrated rubber latex factories (currently over 60 factories, mainly in Southern Thailand) are notorious for air and water pollution, giving rotten egg smell and high nitrogen effluent [4].

Rubber latex effluent (LTE) is characterized by medium organic content $(10,000<\mathrm{COD}<30,000$ $\mathrm{mg} / \mathrm{L})$, high nitrogen content $(500<\mathrm{TN}<1,500 \mathrm{mg} / \mathrm{L})$, high ammonia $\left(300<\right.$ Total $\left.\mathrm{NH}_{3}<1,000 \mathrm{mg} / \mathrm{L}\right)$ 
and high sulfate $\left(500<\mathrm{SO}_{4}<2,000 \mathrm{mg} / \mathrm{L}\right)$ [9,11]. Due to a low operating cost and high COD removal efficiency, anaerobic digestion (AD) is now widely used to treat rubber latex effluent (LTE) [9]. However, the methane yield is relatively low and cleaning the biogas for gas engine is costly due to the high sulfate concentration in LTE and high $\mathrm{H}_{2} \mathrm{~S}$ in the resulting biogas [6,7].

In concentrated rubber latex factories, sulfuric acid is added heavily to recover rubber particles in skim latex, resulting in sulfate-rich effluent which, by the work of sulfate reducing bacteria, produces $\mathrm{H}_{2} \mathrm{~S}$, causing inhibitory effect to anaerobic microbes even at the low concentration of 0.002-003 $\mathrm{M}$ [3]. One way to improve the methane yield in anaerobic digestion of LTE is to substitute hydroxypropyl methylcellulose polymer (HPMC) for sulfuric acid in rubber recovery from skim latex. As illustrated by Chaiprapat et al. [4], HPMC substitution changed wastewater characteristics and increase the biogas yield by more than 2.5 times in batch assay as well as in continuous operation.

Co-digestion of LTE with other wastewater provides another strategy to dilute sulfate concentration as well as complement it with more balance nutrients. Kongjan et al. [7] studied the biochemical hydrogen and methane potential (BHP and BMP) of the co-digestion of skim latex serum (SLS: the main part of LTE) and POME at various mixing ratio under thermophilic condition $\left(55^{\circ} \mathrm{C}\right)$. They found that mixing ratio of $55 \%$ SLS: $45 \%$ POME gave the optimum yield which could produce hydrogen yield of $84.5 \pm 0.7 \mathrm{~mL} \mathrm{H}_{2} / \mathrm{g}-\mathrm{VS}_{\text {added }}$ in 1st stage and methane yield of $311.2 \pm 8 \mathrm{~mL} \mathrm{CH}_{4} / \mathrm{g}^{-\mathrm{VS}_{\text {added }}}$ in the 2 nd stage. Co-digestion of SLS and POME resulted in synergistic effect that potentially could improve the overall $\mathrm{H}_{2}$ and $\mathrm{CH}_{4}$ yields significantly. However, currently there is no practical use of this synergistic effect in an industrial scale. Furthermore, the long-term stability of this kind of continuous AD codigestion system has not been thoroughly investigated so it is risky to come up with all positive conclusion. In fact, there was an incident occurred in 1 pair of factories in Southern Thailand where rubber latex effluent, LTE is anaerobically co-digested with POME (50\% POME: $50 \%$ LTE) in an industrial scale biogas plant. It was found that the plant failed within 75 days of operation. The failure dynamics of the incident was not clear, but it was observed that after 60 days of co-digestion, the $\mathrm{pH}$ dropped sharply, and the plant started to fail irreversibly [19].

In this work, we further investigate the potential of co-digestion of POME and LTE both in terms of synergistic effect and process stability particularly to infer what would happen in an industrial-scale biogas plant if this type of co-digestion is to be materialized. Since normally commercial-scaled biogas plants in Thailand operate at mesophilic temperature $\left(30-35{ }^{\circ} \mathrm{C}\right)$ and only biomethane production is economically feasible, we thus, focus on the biochemical methane potential (BMP) of POME-LTE at different mixing ratio within the temperature range of $30-45{ }^{\circ} \mathrm{C}$. We also use Gompertz 2-substrate (GTS) models as tools for data analysis as well as to create a preliminary prediction for the corresponding continuous AD operation. Synergistic effect and potential instability will be inferred based on these BMP data.

\section{Materials and methods}

\section{Biochemical Methane Potential (BMP) tests for POME-LTE Co-digestion}

The inoculum for BMP assays was collected from anaerobic sludge at the bottom of the most active anaerobic digester in a POME biogas plant in Phraseang district, Surat Thani province, Thailand, where POME was collected. The inoculum was tested for specific methanogenic activity (SMA) using the standard method for SMA assay and was found to be $0.0098 \mathrm{gCOD} / \mathrm{gVSS} \cdot \mathrm{d}$. The LTE was collected from the wastewater pond of rubber latex effluent in the concentrated rubber latex plant in Palian district, Trang province, Thailand. The inoculum was kept at $40{ }^{\circ} \mathrm{C}$ and the wastewater was kept at $0-4{ }^{\circ} \mathrm{C}$ until used in the experiments.

The co-digestion experiments were done at 3 different temperatures, namely: $30 \pm 1,40 \pm 1$ and 45 $\pm 1{ }^{\circ} \mathrm{C}$. The $\mathrm{AD}$ experiments were carried out in 300-ml serum bottles which their headspaces were flushed with nitrogen gas to remove oxygen residues. These were then covered by air-tight caps. All experiments were carried out in batch mode for 45 days in triplicates at different mixing ratios of POME: LTE (Table 1) and initial pH of each digester was estimated to 7.0 - 7.7. Biogas generation was measured daily by water displacement method as used by many authors $[1,5,13,14]$. The methane concentration in 
the biogas was measured using Gas Chromatograph (GC-8A Shimadzu) for day 1 to day 13 and analyzed Soluble Chemical Oxygen Demand (SCOD), Total Chemical Oxygen Demand (TCOD), Total solids (TS), Volatile solids (VS), pH, Alkalinity (Alk), Volatile fatty acid (VFA) and Temperature were performed in accordance with standard methods of APHA [16].

Table 1 summarizes the design of the BMP experiments as well as the initial VS and COD of each batch. It should be noted that the COD: VS ratios are consistent with most of the previous work and it is a typical value for agro-industrial wastewater.

Table 1 BMP test design for POME: LTE Co-digestion.

\begin{tabular}{cccccccc}
\hline \multirow{2}{*}{ Digester } & $\begin{array}{c}\text { Mixing ratio of } \\
\text { POME : LTE }\end{array}$ & \multicolumn{2}{c}{ Wastewater $(\mathbf{m l})$} & Inoculum & VS (mg/L) & $\begin{array}{c}\text { COD } \\
(\mathbf{m g} / \mathbf{L})\end{array}$ & COD/VS \\
\cline { 3 - 4 } & POME & LTE & $(\mathbf{m l})$ & & 40,200 & 65,600 & 1.63 \\
D1 & $100: 0$ & 40 & 0 & & 32,620 & 57,600 & 1.77 \\
D2 & $90: 10$ & 36 & 4 & & 32,060 & 49,600 & 1.55 \\
D3 & $80: 20$ & 32 & 8 & & 37,360 & 60,800 & 1.63 \\
D4 & $70: 30$ & 28 & 12 & & 35,480 & 57,600 & 1.62 \\
D5 & $60: 40$ & 24 & 16 & & 31,800 & 52,800 & 1.66 \\
D6 & $50: 50$ & 20 & 20 & 160 & 34,420 & 56,000 & 1.62 \\
D7 & $40: 60$ & 16 & 24 & & 34,400 & 56,000 & 1.62 \\
D8 & $30: 70$ & 12 & 28 & & 30,060 & 49,600 & 1.65 \\
D9 & $20: 80$ & 8 & 32 & & 27,680 & 44,800 & 1.61 \\
D10 & $10: 90$ & 4 & 36 & & 22,240 & 36,800 & 1.65 \\
D11 & $0: 100$ & 0 & 40 & & & &
\end{tabular}

\section{Mathematical modeling}

In the Gompertz 2-substrate model, Noynoo et al. [12] postulated that the specific growth rate follows the following relation:

$\mu=\mu_{\mathrm{e}} \mathrm{e}^{-\alpha_{\mathrm{e}} \mathrm{t}}+\dot{\mathrm{g}}(\mathrm{t}) \mu_{\mathrm{s}} \mathrm{e}^{-\alpha_{\mathrm{s}} \mathrm{t}}$

Here $\dot{g}(t)$ is the derivative of switching function, describing how the microorganisms switch from 1 substrate type to another. The researchers developed 3 variants of the model based on how the switching function is represented:

Model I: set $g(t)=1$,

$$
\begin{aligned}
& \mathrm{P}^{\prime}=\mathrm{P}_{\mathrm{e}}^{\prime}+\mathrm{P}_{\mathrm{s}}^{\prime}=\left(\mathrm{P}_{\mathrm{e} \infty}+\mathrm{P}_{\mathrm{e} 0}^{\prime}\right) \theta_{\mathrm{e}}+\left(\mathrm{P}_{\infty}-\mathrm{P}_{\mathrm{e} \infty}+\mathrm{P}_{\mathrm{s} 0}^{\prime}\right) \theta_{\mathrm{s}} \\
& \theta_{\mathrm{e}}=\exp \left(-\exp \left(\left(\mathrm{R}_{\mathrm{me}} \mathrm{e} / \mathrm{P}_{\mathrm{e} \infty}^{\prime}\right)\left(\lambda_{\mathrm{e}}-\mathrm{t}\right)+1\right)\right) \\
& \theta_{\mathrm{s}}=\exp \left(-\exp \left(\left(\mathrm{R}_{\mathrm{ms}} \mathrm{e} / \mathrm{P}_{\mathrm{s} \infty}^{\prime}\right)\left(\lambda_{\mathrm{s}}-\mathrm{t}\right)+1\right)\right)
\end{aligned}
$$

where $\theta$ is fractional conversions of digestible substrates, $\mathrm{P}^{\prime}=\mathrm{P}+\mathrm{P}_{0}^{\prime}$ is the total accumulative biogas generated, $\mathrm{P}_{0}^{\prime}$ is the amount of biogas produced by active biomass before the experiment starts and $\mathrm{P}$ is the observed biogas after the AD process starts. $\mu$ is specific growth rate of micro-organisms, $\mathrm{P}_{\infty}$ is the final $(\mathrm{t} \rightarrow \infty)$ biogas accumulated and the switching time $\left(\tau_{\mathrm{s}}\right)$, switch gain kappa $(\kappa)$, lag-time $(\lambda), \mathrm{R}_{\mathrm{m}}$ is 
the maximum specific biogas production rates. e is a constant (2.7183). The subscripts e and s represent easily and slowly degradable substances respectively.

Model II: where switching/preference function $\mathrm{g}(\mathrm{t})$ is chosen as,

$\mathrm{P}^{\prime}=\left(\mathrm{P}_{\mathrm{e} \infty}+\mathrm{P}_{\mathrm{e} 0}^{\prime}\right) \theta_{\mathrm{e}}+\mathrm{g}(\mathrm{t})\left(\mathrm{P}_{\infty}-\mathrm{P}_{\mathrm{e} \infty}+\mathrm{P}_{\mathrm{s} 0}^{\prime}\right) \theta_{\mathrm{s}}$

$\mathrm{g}(\mathrm{t})=(1 / \pi)\left(\tan ^{-1}\left(\kappa\left(\mathrm{t}-\tau_{\mathrm{s}}\right)\right)+(\pi / 2)\right)$

Model III: which is essentially a subset of model II where we set $\lambda_{\mathrm{s}}=0$.

Noynoo et al. [12] proposed that typical ABE curves could be classified by 4 hypothetical types based on the distribution of easily and slowly degradable present in the wastewater (Figure 1).

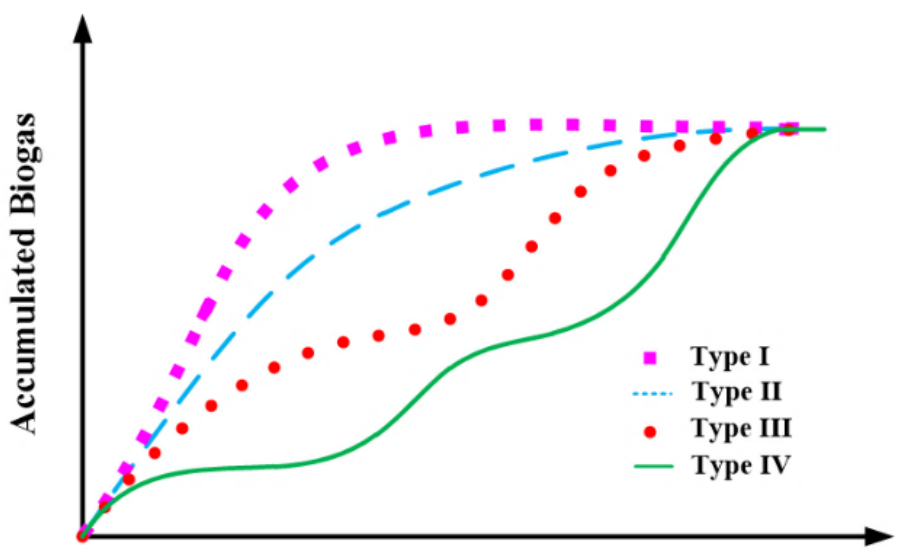

Time

Figure 1 Types of ABE curve [12].

Type I represents $\mathrm{ABE}$ curves involving single substrate which is consumed of essentially single group of microorganisms. Typically, the curves can be described well by Monod kinetics or Gompertztype equations.

Type II is for ABE curves resulted from the environment where multiple substrates were consumed in parallel of sequential by 1 or multiple groups of microorganisms. Traditional single-substrate Monodtype or Gompertz-type models cannot describe the ABE curve adequately.

Type III represents the cases where multiple substrates exist, but they can be simplified by 3 categories: readily degradable, slowly degradable substrates and intermediates.

Type IV is more complex since Type III models would not describe the ABE curve adequately.

The described Gompertz 2-substrate models were designed for type I, II and III, not for type-IV ABE curves. Fortunately, we rarely encountered Type IV curves in practice. 


\section{Results and discussion}

The characteristics of wastewater/substrate were analyzed and shown in Table 2.

Table 2 Characteristics of POME and LTE used in the experiments.

\begin{tabular}{lccc}
\hline Characteristics & POME & LTE & Inoculum \\
\hline SCOD (mg/L) & 28,799 & 5,008 & - \\
TCOD (mg/L) & 96,000 & 36,800 & 48,000 \\
Volatile solids (mg/L) & 57,440 & 22,440 & 29,820 \\
pH & 7.6 & 7.3 & - \\
Alkalinity (mg/L) & 6,000 & 2,500 & - \\
Volatile fatty acid (mg/L) & 750 & 750 & - \\
Temperature ( $\mathrm{C})$ & 27.6 & 28.6 & - \\
\hline
\end{tabular}

It was noticed that LTE used in this work had rather high volatile solid $(24,460 \mathrm{mg} / \mathrm{L})$ in comparison with those published data $(10,000-23,000 \mathrm{mg} / \mathrm{L})$ [11]. The fraction of SCOD for POME and LTE was 0.30 and 0.14, respectively, which implies that POME is easier for microorganisms to digest. The VFA/ALK ratio of POME and LTE were $0.125-0.3$ which is considered as within a stable range. The ratio of COD: VS for POME, LTE and the inoculum were 1.67, 1.47 and 1.61 which is consistent with other previous works. We did not measure ammonia nitrogen and sulfate content in LTE and POME. However, many previous works confirm that while in POME ammonia nitrogen and sulfate content is moderate and does not pose significant inhibitory effects at least in short term, ammonia nitrogen and sulfate content in LTE is typically very high (in the range of $300-1,000$ and $500-2,000 \mathrm{mg} / \mathrm{L}$ respectively $[9,11]$.

\section{Accumulated biogas evolution (ABE) curve}

The $\mathrm{ABE}$ curves obtained from the batch $\mathrm{AD}$ experiments are shown in Figures $\mathbf{2}-\mathbf{4}$ and the corresponding methane potentials are summarized in Table 3. The BMP results given in Table $\mathbf{3}$ clearly show that the temperature close to $45{ }^{\circ} \mathrm{C}$ was required in order to make the potential of mixed wastewaters approached their maximum value. (Approximately $550-650 \mathrm{~mL} \mathrm{CH}_{4} / \mathrm{gVS}$ or $440-470 \mathrm{~mL}$ $\mathrm{CH}_{4} / \mathrm{gCOD}$ depending on the component of wastewater) [2,18]. This can be explained that when the temperature got higher from 30 to $45{ }^{\circ} \mathrm{C}$, the mesophilic methane producing microorganisms can utilize the larger percentage of VS due to temperature effect on microbial activities in all reaction steps of anaerobic digestion.

\section{Biogas yields and biochemical methane potentials (BMP)}

The BMP results show that at $30^{\circ} \mathrm{C}$ the digestibility of POME, thus also the BMP, was not different from that of LTE significantly $(315 \mathrm{~mL} \mathrm{CH} / \mathrm{gVS}$ for POME and $334 \mathrm{~mL} \mathrm{CH} / \mathrm{gVS}$ for LTE). Codigestion of POME and LTE had a synergistic effect that when mixing $80-90 \%$ of POME with 10 $20 \%$ of LTE, it enhanced the BMP by 25 - $35 \%$ which could be due to more nutrient balance. However, adding more LTE $(>20 \%$ LTE) diminished the synergistic effects; thus, suppressed the enhanced feature of co-digestion. This behavior could be a result of inhibitors present in LTE which started to show up when its concentration exceeded the threshold limit.

As the temperature got higher from 30 to $45{ }^{\circ} \mathrm{C}$, and the synergistic effects started to lose its momentum, the inhibitory effect associated with LTE could be dominated and could reduce the BMP. At $45{ }^{\circ} \mathrm{C}$, for example, adding $10 \%$ of LTE could enhance the BMP by $11 \%(509 \mathrm{~mL} \mathrm{CH} / \mathrm{gVS}$ for $100 \%$ POME and $565 \mathrm{~mL} \mathrm{CH} 4 / \mathrm{gVS}$ for $90 \%$ POME). However, further increase in \% LTE resulted in the decrease of BMP performance. It seemed that the microorganisms were more susceptible to the presence of inhibitory effects as the temperature got higher while the increased of temperature can enhance the 
substrate biodegradability. Thus, the best result from our experimental set $\left(45{ }^{\circ} \mathrm{C}, 90 \%\right.$ POME: $10 \%$ LTE) occurred when the combined effects of inhibitors, nutrient balance, and other synergistic effects were at its proportionally optimal state. Figure 6 also illustrates the synergistic and inhibitory effects at different temperatures and mixing-ratios for this co-digestion graphically.

Table 3 BMP and biogas yield of AD co-digestion between POME and LTE at different mixing ratio and mesophilic temperatures.

\begin{tabular}{ccccccccccc}
\hline \multirow{2}{*}{ Digester } & $\begin{array}{c}\text { POME: } \\
\text { LTE }\end{array}$ & \multicolumn{3}{c}{ BMP $(\mathbf{m L} \mathbf{C H} / \mathbf{g V S})$} & \multicolumn{3}{c}{ BMP (mLCH $/ \mathbf{g C O D})$} & \multicolumn{4}{c}{$\begin{array}{c}\text { Biogas yield } \\
\text { (mLBiogas/gVS) }\end{array}$} \\
\cline { 3 - 11 } & & $\mathbf{3 0}^{\circ} \mathbf{C}$ & $\mathbf{4 0}^{\circ} \mathbf{C}$ & $\mathbf{4 5}^{\circ} \mathbf{C}$ & $\mathbf{3 0}^{\circ} \mathbf{C}$ & $\mathbf{4 0}^{\circ} \mathbf{C}$ & $\mathbf{4 5}^{\circ} \mathbf{C}$ & $\mathbf{3 0}^{\circ} \mathbf{C}$ & $\mathbf{4 0}^{\circ} \mathbf{C}$ & $\mathbf{4 5}^{\circ} \mathbf{C}$ \\
\hline 1 & $100: 0$ & 315 & 412 & 509 & 193 & 253 & 312 & 626 & 728 & 964 \\
2 & $90: 10$ & 422 & 441 & 565 & 239 & 250 & 319 & 788 & 818 & 1,009 \\
3 & $80: 20$ & 396 & 426 & 430 & 256 & 276 & 278 & 742 & 788 & 787 \\
4 & $70: 30$ & 332 & 350 & 390 & 204 & 215 & 240 & 625 & 654 & 716 \\
5 & $60: 40$ & 321 & 373 & 401 & 198 & 230 & 247 & 619 & 694 & 772 \\
6 & $50: 50$ & 334 & 390 & 410 & 201 & 235 & 247 & 641 & 752 & 805 \\
7 & $40: 60$ & 300 & 347 & 405 & 185 & 213 & 249 & 596 & 688 & 805 \\
8 & $30: 70$ & 330 & 309 & 396 & 203 & 190 & 244 & 615 & 614 & 770 \\
9 & $20: 80$ & 333 & 340 & 508 & 202 & 206 & 308 & 662 & 721 & 957 \\
10 & $10: 90$ & 324 & 352 & 506 & 200 & 217 & 312 & 692 & 772 & 945 \\
11 & $0: 100$ & 304 & 360 & 479 & 184 & 217 & 290 & 659 & 789 & 984 \\
\hline
\end{tabular}




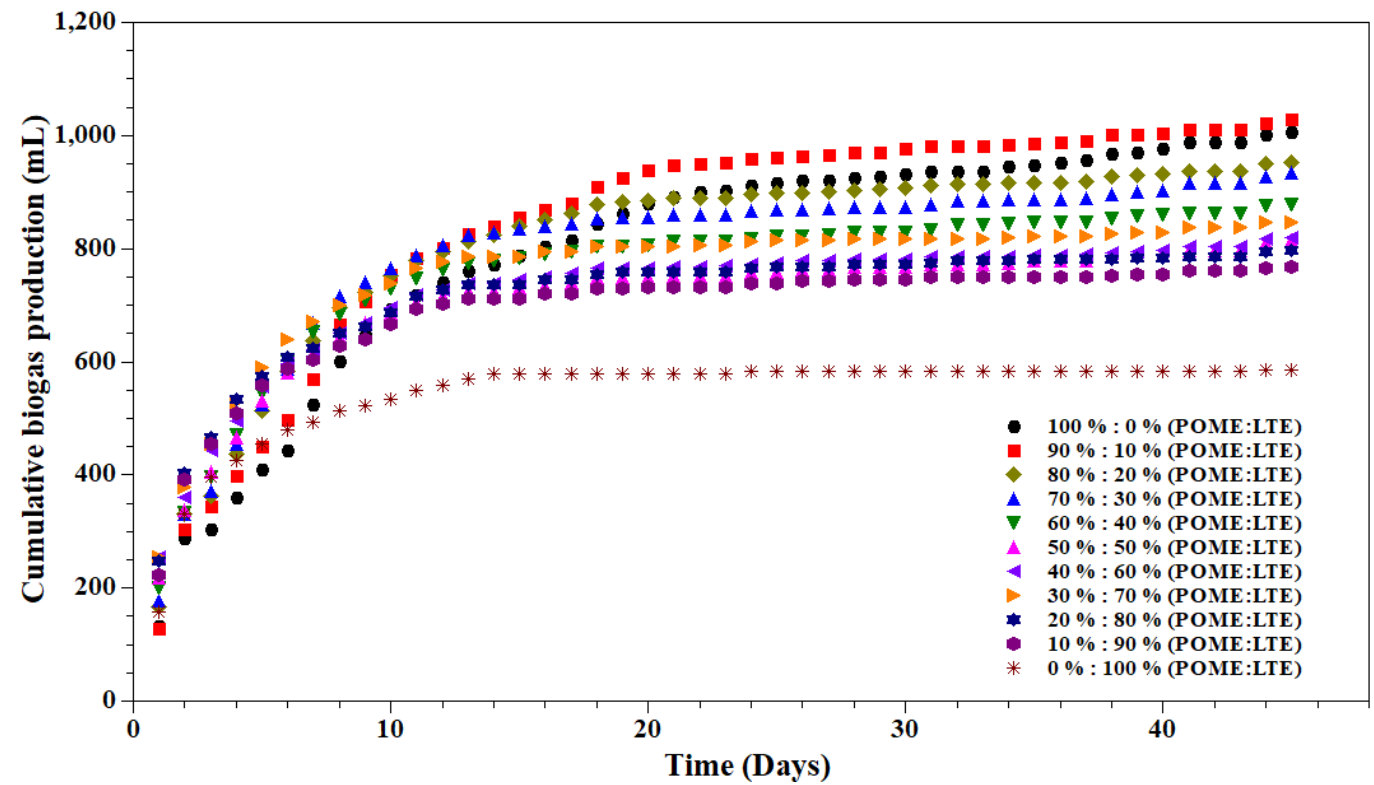

Figure 2 Cumulative biogas production from anaerobic co-digestion of inoculum with POME and LTE at $30{ }^{\circ} \mathrm{C}$.

As summarized in Table 3, in the mesophilic temperature range $\left(30-45^{\circ} \mathrm{C}\right)$, higher biogas yield and BMP was associated with higher temperatures. Co-digestion results showed synergistic effect when mixing POME: LTE ratio is higher than $50: 50 \%$. Thus the best POME: LTE ratio was $90: 10 \%$ as this gives highest biogas yield and a BMP of 1,009 and $565 \mathrm{~mL} / \mathrm{gVS}$ respectively. This yield is comparable to that of Kongjan et al. [7] in which they found that mixing ratio of $55 \%$ LTE: $45 \%$ POME gave the optimum yield which could produce hydrogen yield of $84.5 \pm 0.7 \mathrm{~mL} \mathrm{H} / \mathrm{g}_{2} \mathrm{VS}_{\text {added }}$ in 1 st stage and methane yield of $311.2 \pm 8 \mathrm{~mL} \mathrm{CH} 4 / \mathrm{g}-\mathrm{VS}_{\text {added }}$ in the 2 nd stage. This is only a rough comparison because they did the experiment at different temperature $\left(55^{\circ} \mathrm{C}\right)$ and the substrate was not identical. 


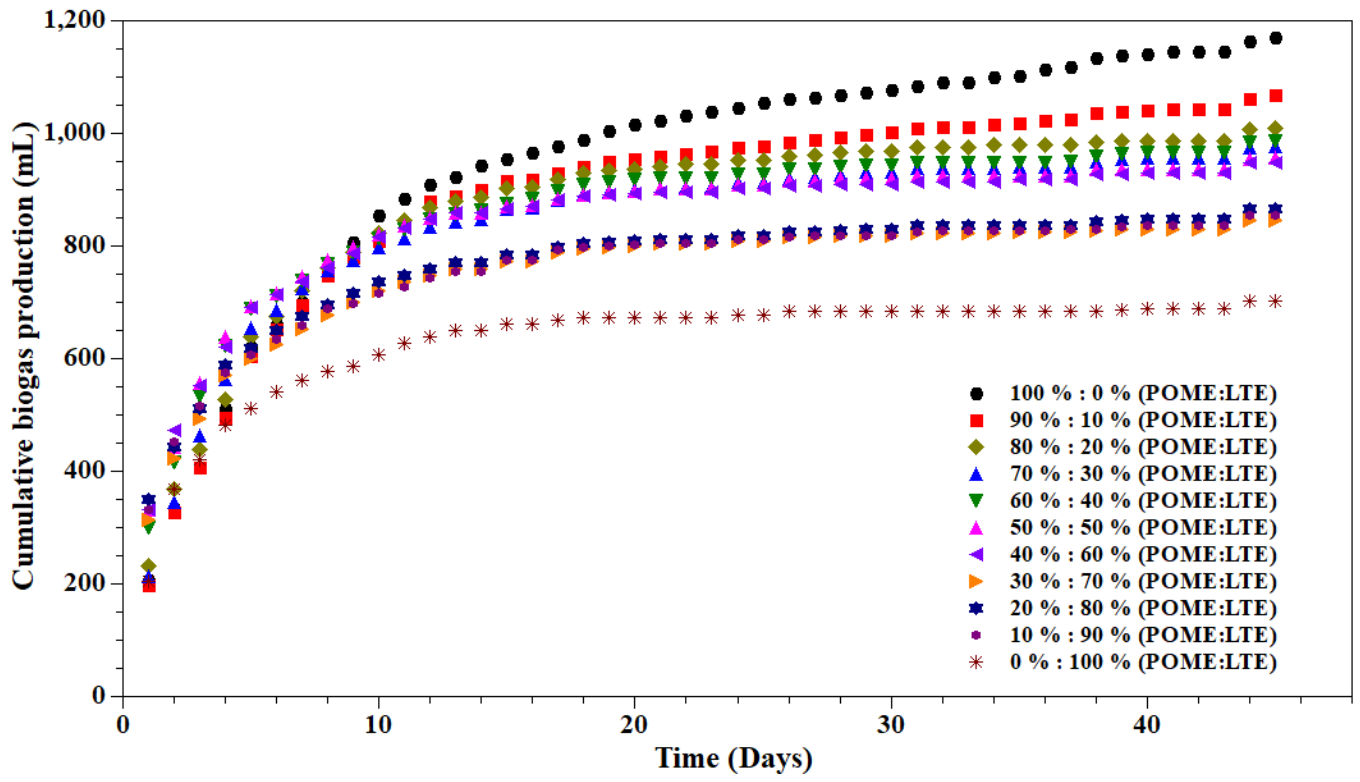

Figure 3 Cumulative biogas production from anaerobic co-digestion of inoculum with POME and LTE at $40^{\circ} \mathrm{C}$

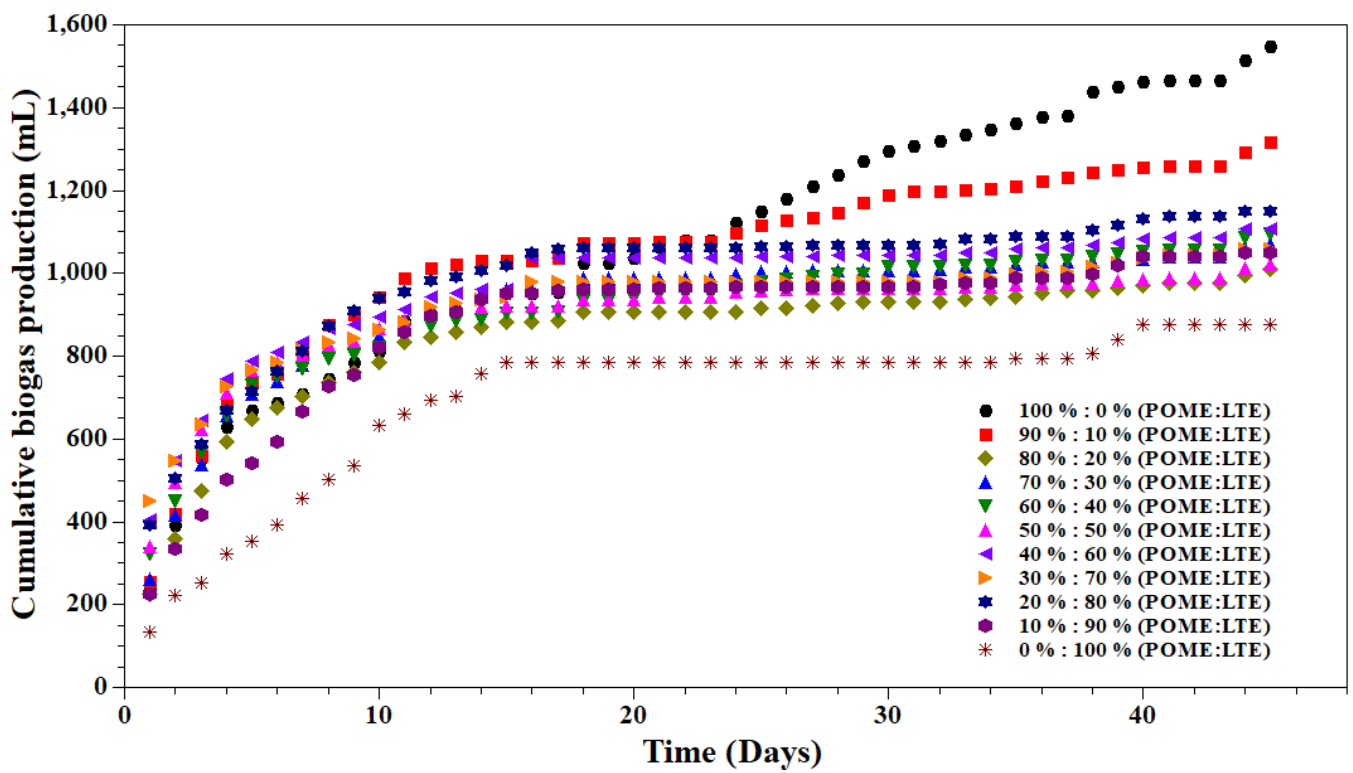

Figure 4 Cumulative biogas production from anaerobic co-digestion of inoculum with POME and LTE at $45{ }^{\circ} \mathrm{C}$. 


\section{Methane production}

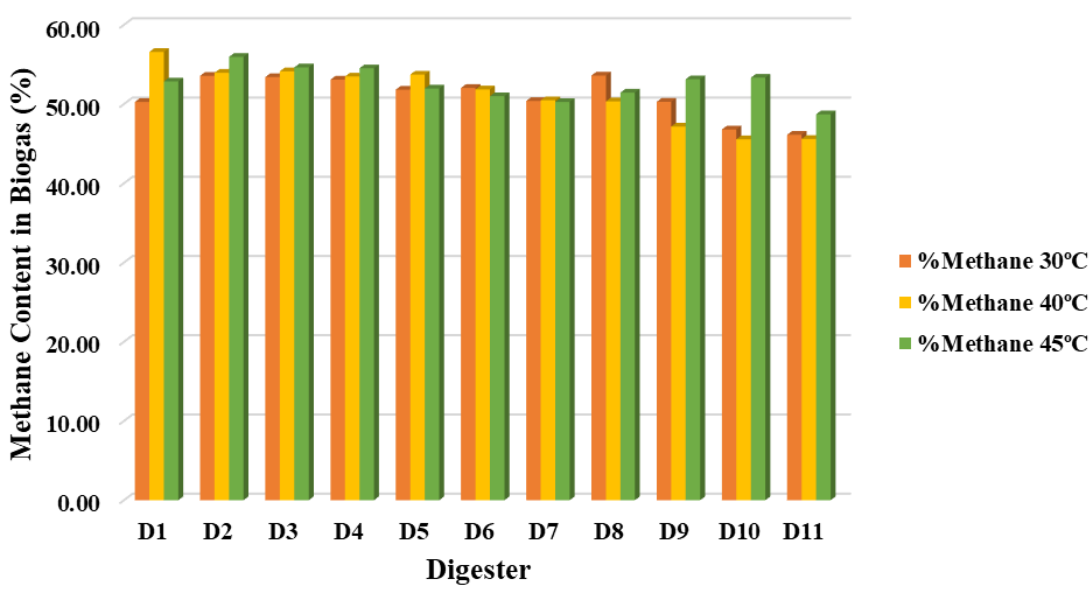

Figure 5 Methane content in biogas from anaerobic co-digestion of POME-LTE at difference mixing ratio and temperature.

The effect of temperature and \% LTE

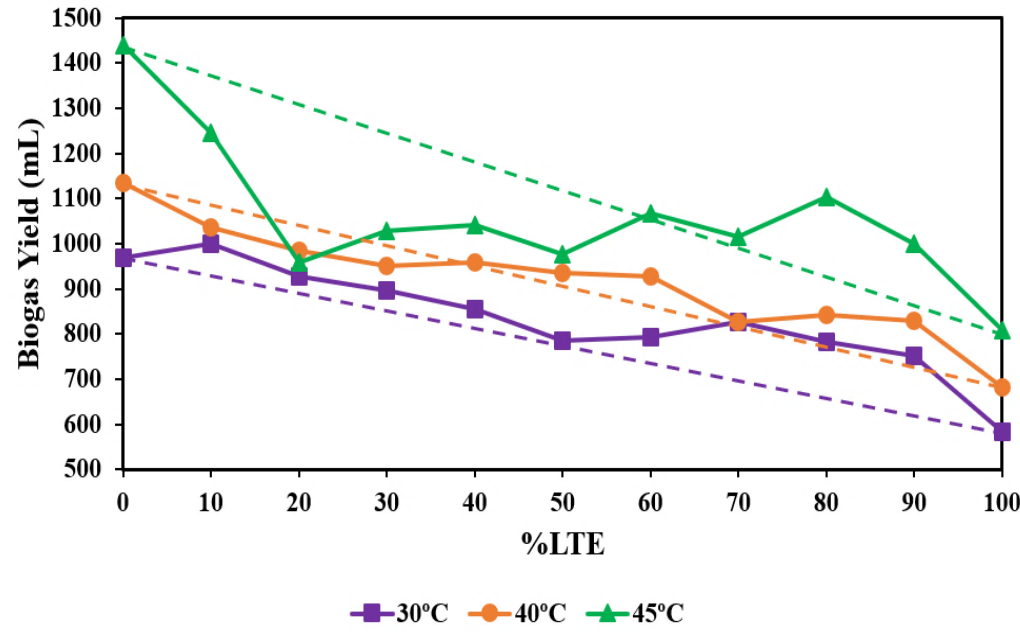

Figure 6 Cumulative biogas yield versus \% LTE at all temperature.

(Dashed lines are hypothetically linear trends)

On average, the best methane (53 - $55 \%$ methane) was obtained when the synergistic effects were dominated. As shown in Figure 5, for the temperature range of $30-40{ }^{\circ} \mathrm{C}$, the synergistic effects were optimal when LTE was less than $30 \%$. Except for $45{ }^{\circ} \mathrm{C}$, higher proportion of LTE $(>30 \%)$ reduced the percentage of methane in biogas gradually. Pure LTE gave lowest methane content for all temperature in the current experimental range $\left(30-45^{\circ} \mathrm{C}\right)$. Surprisingly, at $45^{\circ} \mathrm{C}$, there was a synergistic effect occurred when 10 - $20 \%$ POME was co-digested with 80 - 90\% LTE. The increased of methane content (as well as BMP) was significant as it was raised above $50 \%$ threshold (suitable for generating electricity by gas 
engines). These did not happen for 30 and $40{ }^{\circ} \mathrm{C}$. Overall, temperature of $45^{\circ} \mathrm{C}$ did not give the highest methane yields and higher methane percentage.

\section{Modeling and model fitting}

In order to obtain another level of insight from this set of experimental data, we used the Gompertz approach to describe the whole set of $\mathrm{ABE}$ data. The preliminary conclusions are presented below:

1. While it is acceptable to use members of traditional Gompertz-type model such as Gompertz, logistic, Richards, exponential or Schnute equations to describe or represent some ABE curves obtained from our set of experiments, they did not fit well, and the error seemed systematic one. That is if one tries to fit the initial and final periods of the ABE curves, the middle period would be overestimated/predicted. Likewise, if the weight is placed on the middle period (5 - 20 days), the prediction for both initial and final periods was systematically off the model trend.

2. We tried to fit the data with a simple single-substrate Monod kinetics and the same preliminary results were similar to that of traditional Gompertz-family models.

3. Furthermore, some ABE curves exhibited 2 plateaus one at the initial-to-middle period (10 - 20 days) and another one occurred in the final period ( $>25$ days).

4. The observation in (1) to (3) suggested that the ABE curves should be better described by the coexistence of multiple substrates. However, to simplify the model, we proposed that 2 groups of substrates would be enough for model development for this type of co-digestion. So, the so-called "Gompertz 2substrate (GTS) model" was developed by Noynoo et al. [12] and used in our analysis in this article.

The results of model fitting are depicted and summarized in Figure 7 - 9 and Table 4 - 6 respectively.

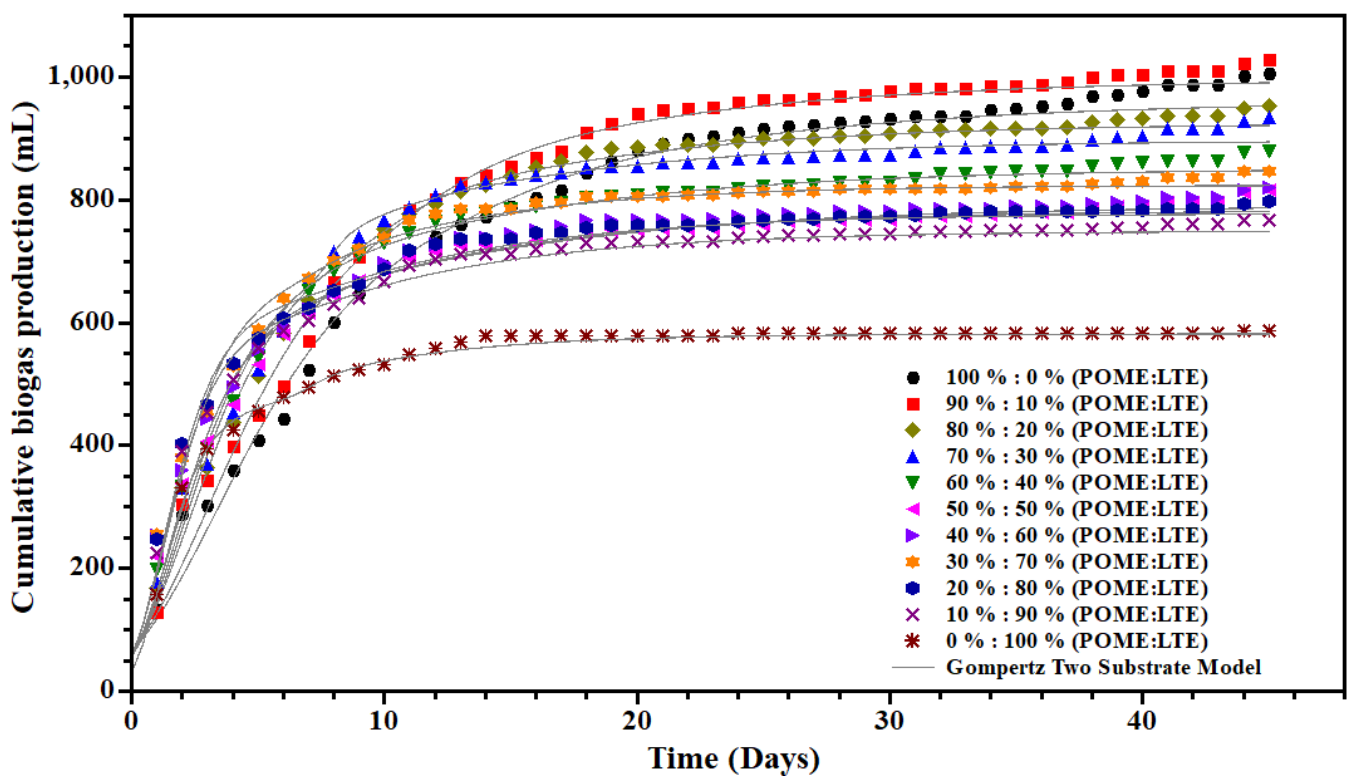

Figure 7 Cumulative biogas production of inoculum with POME: LTE at $30^{\circ} \mathrm{C}$ for GTS model. 


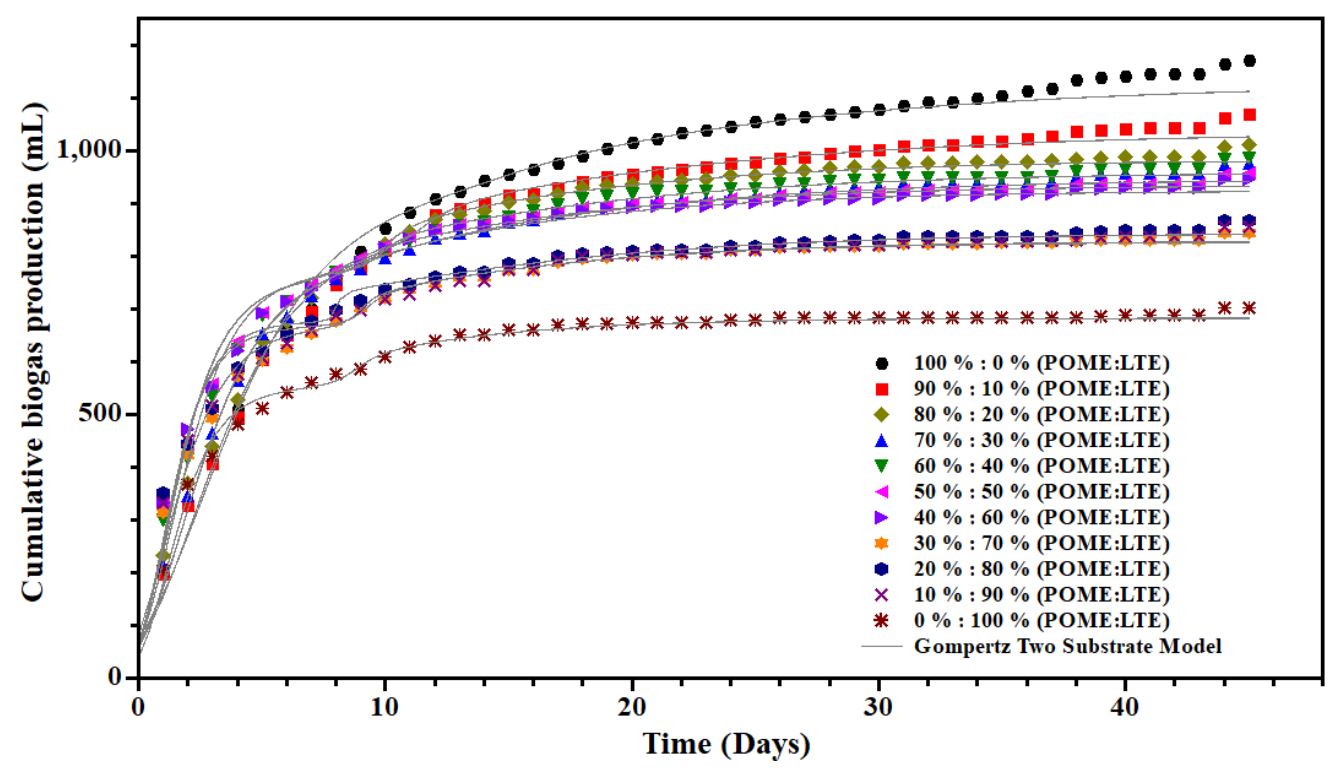

Figure 8 Cumulative biogas production of inoculum with POME: LTE at $40{ }^{\circ} \mathrm{C}$ for GTS model.

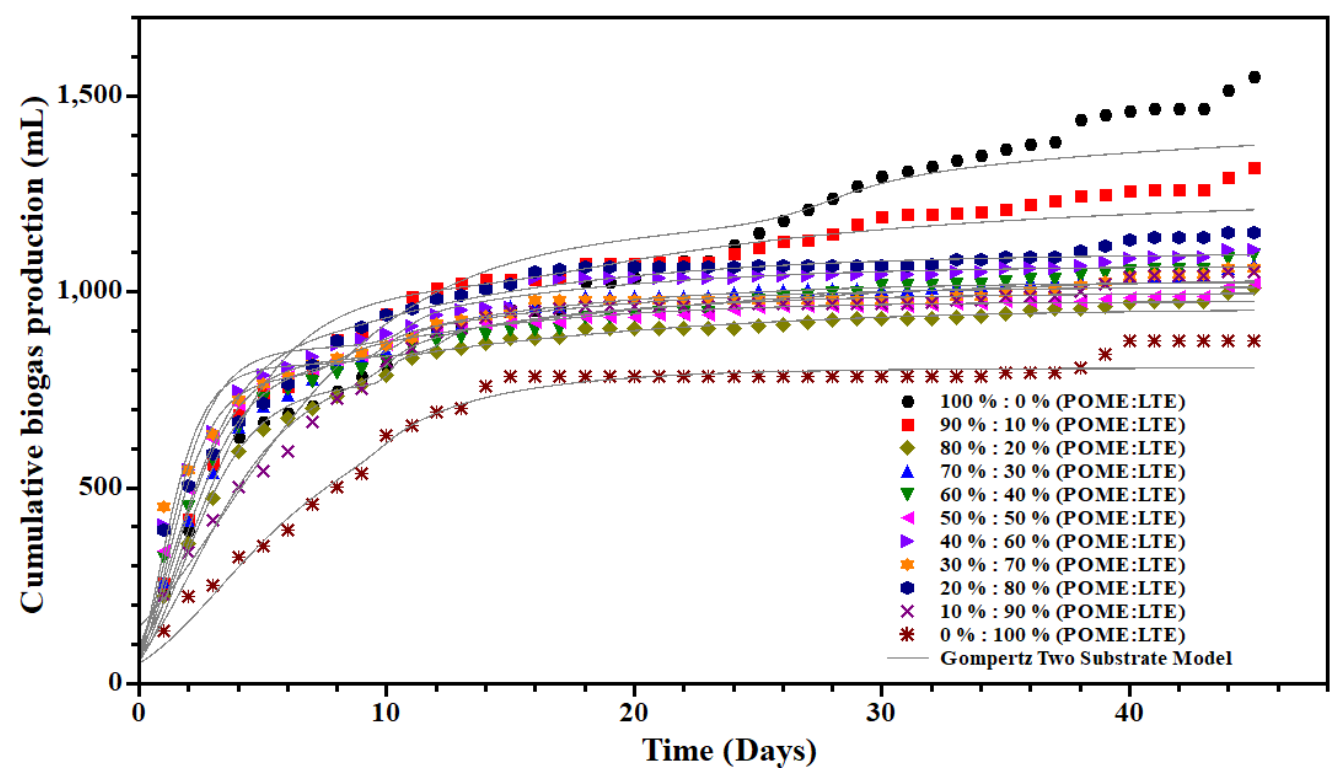

Figure 9 Cumulative biogas production of inoculum with POME: LTE at $45{ }^{\circ} \mathrm{C}$ for GTS model. 
Table 4 Parameters and the best-fit parameter $\left(\mathrm{R}^{2}\right)$ of cumulative biogas production at $30{ }^{\circ} \mathrm{C}$.

\begin{tabular}{ccccccccccc}
\hline \multirow{2}{*}{ Model } & \multirow{2}{*}{ Digester } & \multicolumn{8}{c}{ Parameter } \\
\cline { 3 - 10 } & $\mathbf{P}_{\infty}$ & $\mathbf{P}_{\mathbf{e} \infty}$ & $\mathbf{R}_{\mathbf{m s}}$ & $\mathbf{R}_{\mathbf{m e}}$ & $\boldsymbol{\kappa}$ & $\boldsymbol{\lambda}_{\mathrm{e}}$ & $\boldsymbol{\lambda}_{\mathbf{s}}$ & $\mathbf{t}_{\mathbf{r}}$ & $\mathbf{R}^{\mathbf{2}}$ \\
\hline \multirow{5}{*}{ Gompertz } & D1 & 968.3 & 774.6 & 6.99 & 79.5 & 0.2049 & -0.2831 & 0 & 14.34 & 0.9876 \\
& D2 & $1,000.8$ & 800.6 & 7.91 & 91.2 & 0.3205 & -0.2219 & 0 & 11.82 & 0.9904 \\
& D3 & 926.9 & 741.5 & 7.95 & 113.0 & 0.5461 & -0.1740 & 0 & 11.02 & 0.9918 \\
& D4 & 897.0 & 717.6 & 8.03 & 124.7 & 2.2971 & -0.1126 & 0 & 7.90 & 0.9903 \\
& D5 & 854.1 & 683.2 & 7.48 & 128.5 & 0.3269 & -0.1482 & 0 & 7.76 & 0.9907 \\
& D6 & 785.5 & 628.4 & 7.51 & 137.1 & 0.3832 & -0.1651 & 0 & 7.74 & 0.9874 \\
& D7 & 793.3 & 634.6 & 6.97 & 136.1 & 0.2793 & -0.1646 & 0 & 7.59 & 0.9872 \\
& D8 & 827.4 & 661.9 & 9.75 & 164.8 & 0.5168 & -0.1462 & 0 & 7.47 & 0.9885 \\
& D9 & 781.4 & 625.1 & 8.54 & 178.3 & 0.3218 & -0.1073 & 0 & 7.77 & 0.9869 \\
& D10 & 752.6 & 602.0 & 8.44 & 171.1 & 0.3371 & -0.1244 & 0 & 7.72 & 0.9881 \\
& D11 & 582.7 & 466.1 & 8.52 & 159.9 & 0.9307 & 0.0138 & 0 & 6.98 & 0.9943 \\
\hline
\end{tabular}

Table 5 Parameters and the best-fit parameter $\left(\mathrm{R}^{2}\right)$ of cumulative biogas production at $40{ }^{\circ} \mathrm{C}$.

\begin{tabular}{ccccccccccc}
\hline \multirow{2}{*}{ Model } & Digester & \multicolumn{8}{c}{ Parameter } & \multicolumn{1}{c}{} \\
\cline { 3 - 10 } & & $\mathbf{P}_{\infty}$ & $\mathbf{P}_{\mathbf{e} \infty}$ & $\mathbf{R}_{\mathbf{m s}}$ & $\mathbf{R}_{\mathbf{m e}}$ & $\boldsymbol{\kappa}$ & $\boldsymbol{\lambda}_{\mathrm{e}}$ & $\boldsymbol{\lambda}_{\mathbf{s}}$ & $\mathbf{t}_{\mathbf{r}}$ & $\mathbf{R}^{2}$ \\
\hline \multirow{5}{*}{ Gompertz } & D1 & $1,134.2$ & 907.3 & 7.09 & 120.1 & 0.2341 & -0.2234 & 0 & 14.56 & 0.9894 \\
& D2 & $1,036.7$ & 829.3 & 6.94 & 128.5 & 0.9956 & -0.1378 & 0 & 11.46 & 0.9931 \\
& D3 & 983.2 & 786.5 & 8.44 & 149.5 & 1.3568 & -0.1306 & 0 & 9.97 & 0.9923 \\
& D4 & 950.3 & 760.2 & 8.12 & 151.9 & 0.2783 & -0.0804 & 0 & 8.75 & 0.9938 \\
& D5 & 959.3 & 767.4 & 7.94 & 197.3 & 1.4168 & -0.1169 & 0 & 9.84 & 0.9895 \\
& D6 & 935.6 & 748.4 & 8.50 & 218.4 & 0.8411 & -0.1225 & 0 & 8.41 & 0.9878 \\
& D7 & 927.2 & 741.7 & 9.04 & 218.8 & 0.3859 & -0.1390 & 0 & 8.30 & 0.9842 \\
& D8 & 827.4 & 661.9 & 8.15 & 176.5 & 1.8952 & -0.3687 & 0 & 8.95 & 0.9859 \\
& D9 & 843.1 & 674.4 & 7.38 & 232.6 & 7.4069 & -0.1305 & 0 & 8.06 & 0.9788 \\
& D10 & 828.6 & 662.8 & 8.13 & 234.4 & 1.5816 & -0.1079 & 0 & 9.22 & 0.9803 \\
& D11 & 683.1 & 546.4 & 8.79 & 176.2 & 1.2441 & -0.0276 & 0 & 8.76 & 0.9924 \\
\hline
\end{tabular}

Table 6 Parameters and the best-fit parameter $\left(\mathrm{R}^{2}\right)$ of cumulative biogas production at $45^{\circ} \mathrm{C}$.

\begin{tabular}{ccccccccccc}
\hline \multirow{2}{*}{ Model } & Digester & \multicolumn{10}{c}{ Parameter } & \multicolumn{1}{c}{} \\
\cline { 3 - 11 } & & $\mathbf{P}_{\infty}$ & $\mathbf{P}_{\mathbf{e} \infty}$ & $\mathbf{R}_{\mathbf{m s}}$ & $\mathbf{R}_{\mathbf{m e}}$ & $\mathbf{K}$ & $\boldsymbol{\lambda}_{\mathbf{e}}$ & $\boldsymbol{\lambda}_{\mathbf{s}}$ & $\mathbf{t}_{\mathbf{r}}$ & $\mathbf{R}^{2}$ \\
\hline \multirow{5}{*}{ Gompertz } & D1 & $1,439.0$ & 1151.2 & 6.07 & 93.5 & 0.3795 & -1.2185 & 0 & 27.69 & 0.9337 \\
& D2 & $1,245.6$ & 996.4 & 6.87 & 159.1 & 0.1869 & -0.2480 & 0 & 17.76 & 0.9738 \\
& D3 & 957.8 & 766.2 & 7.30 & 163.9 & 4.4465 & -0.0742 & 0 & 10.12 & 0.9910 \\
& D4 & $1,027.3$ & 821.8 & 9.30 & 190.5 & 1.1851 & -0.0784 & 0 & 10.51 & 0.9920 \\
& D5 & $1,041.3$ & 833.0 & 6.38 & 205.1 & 1.6889 & -0.1482 & 0 & 12.22 & 0.9782 \\
& D6 & 976.8 & 781.4 & 10.28 & 264.5 & 1.2286 & -0.0403 & 0 & 7.91 & 0.9895 \\
& D7 & $1,067.9$ & 854.3 & 9.82 & 276.1 & 1.1801 & -0.1143 & 0 & 10.78 & 0.9797 \\
& D8 & $1,014.7$ & 811.7 & 9.36 & 306.9 & 1.5961 & -0.1178 & 0 & 9.87 & 0.9698 \\
& D9 & $1,103.9$ & 883.1 & 10.14 & 194.9 & 0.2671 & -0.3210 & 0 & 9.38 & 0.9674 \\
& D10 & 999.0 & 799.2 & 9.43 & 121.3 & 1.2475 & -0.2670 & 0 & 10.01 & 0.9838 \\
& D11 & 807.5 & 646.0 & 9.59 & 69.4 & 0.8367 & -0.2470 & 0 & 9.85 & 0.9763 \\
\hline
\end{tabular}


In fitting the $\mathrm{ABE}$ data to Gompertz 2-substrate model, we firstly evaluated the best percentage of easily degradable by non-constrained least square model fitting. We found that the best estimated fraction of easily degradable was in the range of $15-25 \%$. Thus, taking the average value $20 \%$, all parameter estimations in Tables 4 - $\mathbf{6}$ were based on this assumption.

It should be noticed that the biogas production rate for easily digestible substrate $\left(R_{m e}\right)$ is about 10 20 times that of slowly digestible substrate $\left(\mathrm{R}_{\mathrm{ms}}\right)$. The initial lag-time has a negative sign for all experiments. This indicated that, in the experimental setup, the amount of active microbial biomass was in excess and for a short period of digestion, the microbes started to be deprived of limiting substrate, causing the appearance of negative lag-time. It was also observed that kappa tended to increase as temperature got higher, indicating more preference on the easily digestible. Whereas the digestion of slowly degradable substrate was more independent on the easily degradable one. Lastly, it is obvious that as the percentage of POME decreased so did $t_{r}$, indicating later switching to the slowly (less preferable) degradable substrate.

\section{Conclusions}

Proper co-digestion between POME and LTE provided a good opportunity to optimize the biomethane yield because of their synergistic effect. The mixing POME: LTE ratio of more than 0.5 showed synergistic effect for all temperatures in the experimental range $\left(30-45^{\circ} \mathrm{C}\right)$. It is also recommended that, in mesophilic range, $45{ }^{\circ} \mathrm{C}$ would be the best for both methane yield and high methane content in the biogas. We also have illustrated that 2-substrate models (in this case the GTS model) are very suitable for representing and describing co-digestion data because of their inherently multiple substrate tendency. It is recommended that, for most batch co-digestion experiments appeared in the literature, Gompertz/Logistic 2-substrate models should be used to describe the accumulated methane/biogas data instead of the traditional, single-substrate, Gompertz type models. This can be anticipated by considering the fact that one of the advantages of co-digestion is the presence of at least 2 types of substrates (which is traditionally classified as easily and slowly digestible substrates). They have different degrees of digestibility which help to release the carbon sources in such a way that the growth between acidogens and methenogens is balanced and synchronized, keeping $\mathrm{pH}$ and VFA/ALK at the optimal range for methane production. This will ensure high methane yield and good process stability [15].

Furthermore, as mentioned earlier, there was an incident occurred in an industrial-scale biogas plant where LTE is anaerobically co-digested with POME (50\% POME: $50 \%$ LTE) in an industrial scale biogas plant. It was found that the plant failed within 75 days of operation. It was observed that after 60 days of co-digestion, the $\mathrm{pH}$ dropped sharply, and the plant started to fail irreversibly [19]. Thus, it is anticipated that the optimum/synergistic POME: LTE ratio $(>0.5)$ found in this work may not be applied directly to the continuous system with prolonged operation. In these cases, the accumulation of toxic substances including free ammonia and hydrogen sulfide must be suppressed to a minimum level to ensure stable operation. This problem needs further investigation.

\section{Acknowledgements}

The authors would like to thank Walailak University Fund and Biomass and Oil-Palm Excellence Center, Walailak University grant for financial support.

\section{References}

[1] MA Abdel-Hadi. A simple apparatus for biogas quality determination. J. Agric. Eng. 2008; 25, 1055-66.

[2] S Achinas and GJ Euverink. Theoretical analysis of biogas potential prediction from agricultural waste. Resource Efficient Technol. 2016; 2, 143-7.

[3] D Batstone, J Keller, I Angelidaki, S Kalyuzhnyi, S Pavlostathis, A Rozzi and V Vavilin. Anaerobic digestion model No 1 (ADM1). Water Sci. Technol. 2002; 45, 65-73. 
[4] S Chaiprapat, S Wongchana, S Loykulnant, C Kongkaew and B Charnnok. Evaluating sulfuric acid reduction, substitution, and recovery to improve environmental performance and biogas productivity in rubber latex industry. Process Saf. Environ. Prot. 2014; 94, 420-9.

[5] S Dechrugsa, D Kantachote and S Chaiprapat. Effects of inoculum to substrate ratio, substrate mix ratio and inoculum source on batch co-digestion of grass and pig manure. Bioresour. Technol. 2013; 146, 101-8.

[6] R Jariyaboon, S O-Thong and P Kongjan. Bio-hydrogen and bio-methane potentials of skim latex serum in batch thermophilic 2-stage anaerobic digestion. Bioresour. Technol. 2015; 198, 198-206.

[7] P Kongjan, R Jariyaboon and S O-Thong. Anaerobic digestion of skim latex serum (SLS) for hydrogen and methane production using a 2-stage process in a series of up-flow anaerobic sludgeblanket (UASB) reactor. Int. J. Hydrog. Energ. 2014; 39, 19343-8.

[8] P Kongjan, K Sama, K Sani, R Jariyaboon and A Reungsang. Feasibility of bio-hythane production by co-digesting skim latex serum (SLS) with palm oil mill effluent (POME) through 2-phase anaerobic process. Int. J. Hydrog. Energ. 2018; 43, 9577-90.

[9] M Mohammadi, HC Man, M Hassan and P Yee. Treatment of wastewater from rubber industry in Malaysia. Afr. J. Biotechnol. 2010; 9, 6233-43.

[10] C Musikavong and S Gheewala. Assessing ecological footprints of products from the rubber industry and palm oil mills in Thailand. J. Clean. Prod. 2016; 142, 1148-57.

[11] H Nguyen and T Luong. Situation of wastewater treatment of natural rubber latex processing in the Southeastern region. J. Viet. Environ. 2012; 2, 58-64.

[12] L Noynoo, S Jijai, K Phayungphan, N Rakmak and C Siripatana. Gompertz-Type 2-Substrate Models for Batch Anaerobic Co-Digestion. Lecture Notes in Applied Mathematics and Applied Science in Engineering. Malaysia Technical Scientist Association, Malaysia, 2019, p. 21-30.

[13] WF Owen, D Stuckey, JB Healy, L Young and PL McCarty. Bioassay for monitoring biochemical methane potential and anaerobic toxicity. J. Water Rese. 1978; 13, 485-92.

[14] J Patil, M Lourdu, A Raj, S Vinaykumar, H Manjunath and A Srinidhi. Biomethanation of water hyacinth, poultry litter, cow manure and primary sludge: A comparative analysis. Res. J. Chem. Sci. $2011 ; \mathbf{1}, 22-6$.

[15] T Rachadaporn, H Thongpan, N Rakmak and C Siripatana. Modeling of anaerobic co-digestion of pig manure and domestic organic waste. J. Teknol. 2016; 78, 117-24.

[16] E Rice and A Association. Standard Method for the Examination of Water and Wastewater. In: RH Strauss (Ed.). American Public Health Association. $23^{\text {rd }}$ ed. Washington DC, 2017.

[17] C Siripatana, S Jijai and P Kongjan. Analysis and extension of Gompertz-type and monod-type equations for estimation of design parameters from batch anaerobic digestion experiments. AIP Conf. Proc. 2016; 1775, 030079.

[18] J Triolo, SG Sommer, H Møller, M Weisbjerg and X Jiang. A new algorithm to characterize biodegradability of biomass during anaerobic digestion: Influence of lignin concentration on methane production potential. Bioresour. Technol. 2011; 102, 9395-402.

[19] N Yingthavorn, N Rakmak, P Kongjan and C Siripatana. Mathematical modeling of existing 2-stage anaerobic digestion process for palm oil mill wastewater. J. Teknol. 2016; 78, 21-6. 